\title{
Penanganan herpes simpleks labialis rekuren (Management of recurrent herpes simplex labialis)
}

\author{
${ }^{1}$ Harlina, ${ }^{1}$ Erni Marlina, ${ }^{2}$ Athifah \\ ${ }^{1}$ Bagian Oral Medicine \\ ${ }^{2}$ Mahasiswa tahap kepaniteraan \\ Fakultas Kedokteran Gigi Universitas Hasanuddin \\ Makassar, Indonesia
}

\begin{abstract}
Infections of Herpes simplex virus 1 (HSV-1), is a viral infection that is often in the form of primary gingivostomatitis. Its mild form usually provides subclinical symptoms that are not clear. Herpes virus transmission can occur through contact with secretions from the mouth mucocutaneous and patient's genital. It is reported that a 10 years-old male patient complaining of pain in the left corner of the lip and lower lip mucosa experienced since three days ago. Seven days ago there was a similar injury in the right corner of his mouth. This condition was often experienced the patient. As its management of HSV-1, the patient was given acyclovir, paracetamol and vitamin B complex. After 7 days the patient was declared healed. It is concluded that treatment for HSV-1 infected patients include causative treatment together with analgesic and antipyretic. Patients are also prouded with supporting treatments, such as high-caloriand-protein diluted food, multivitamins, and anastheticum mouthwasher.
\end{abstract}

Keywords: herpes simplex virus, herpes simplex, labialis herpes simplex

\begin{abstract}
ABSTRAK
Infeksi virus herpes simpleks 1 (VHS-1), merupakan infeksi virus yang lebih sering terjadi dalam bentuk gingivostomatitis primer dan jika dalam bentuk ringan biasanya memberikan gejala subklinis yang tidak jelas. Penularan virus herpes dapat terjadi melalui kontak mukokutaneus dengan sekret dari mulut maupun genital penderita. Pada laporan kasus ini dibahas mengenai penanganan herpes simpleks labialis rekuren pada seorang anak laki-laki berusia 10 tahun yang datang dengan keluhan nyeri pada sudut bibir sebelah kiri dan mukosa bibir bawah yang dialami sejak 3 hari yang lalu. Pada tujuh hari yang lalu, terdapat luka yang sama pada sudut bibir kanan. Dilaporkan juga bahwa kondisi ini sering dialami oleh pasien. Pada penatalaksanaannya pasien diberikan Acyclovir, Paracetamol dan vitamin B kompleks. Setelah 7 hari pasien dinyatakan sembuh. Infeksi VHS-1 pada umumnya tidak bergejala ataupun gejalanya sangat ringan sehingga sering tidak disadari, dan penting untuk dibedakan antara infeksi primer dan sekunder. Disimpulkan bahwa terapi bagi penderita infeksi VHS meliputi terapi kausatif disertai analgesik dan antipiretik, pemberian terapi suportif seperti makanan cair tinggi kalori dan protein, multivitamin, serta obat kumur anastetik.
\end{abstract}

Kata kunci: virus herpes simpleks, herpes simplek, herpes simplek labialis

\section{Koresponden:}

\section{PENDAHULUAN}

Infeksi virus herpes simpleks 1 (VHS-1) yang biasa disebut herpes simpleks labialis (HSL) adalah masalah global kesehatan masyarakat yang memiliki berbagai bentuk pengobatan dengan dampak yang minimal. Bentuk yang paling umum dari infeksi virus tersebut adalah gingivostomatitis primer, atau berupa infeksi berulang HSL, biasanya terjadi pada anak prasekolah atau taman kanak-kanak, remaja, dan dewasa muda. ${ }^{1}$

Herpes simpleks virus merupakan famili dari Herpes viridae yang terdiri dari delapan virus, antara lain cytomegalovirus, varicella zostervirus, eipstein barr, dan human herpes virus VI yang terkait dengan roseola infantum, dan human herpes virus VII yang terkait dengan virus roseola exanthem subitum, pityriasisrosea, serta human herpes virus VIII yang terkait dengan sarcoma kaposi dan limfoma.
Penularan virus herpes dapat terjadi karena kontak mukokutaneus dengan sekret dari mulut maupun genital individu yang terinfeksi. Infeksi herpes disebabkan oleh VHS-1 dan VHS-2 dengan sifat biologis dan serologis yang berbeda. VHS-1 bertanggung jawab terhadap mayoritas kasus infeksi mulut, faring dan meningoensefalitis, serta dermatitis di atas pinggang. Sedangkan VHS-2 disebut dalam mayoritas infeksi genitalia, infeksi pada bayi yang baru lahir, dan dermatitis di bawah pinggang. ${ }^{2,3}$

Prevalensi VHS secara lazim mencapai 33\% di seluruh dunia, $15-45 \%$ terjadi pada orang dewasa yang mengalami herpes simpleks labialis dan memiliki kecenderungan untuk menurun seiring pertambahan usia. Pasien dengan riwayat VHS labialis memiliki prevalensi $30-70 \%$ dengan VHS-1 antibodi. Survei secara klinis sangat meremehkan tingkat kejadian dan prevalensi infeksi VHS sebab lebih dari dua 
pertiga kasus infeksi VHS-1 tidak memperlihatkan adanya gejala. ${ }^{3}$

Manifestasi dari infeksi primer dapat ringan maupun berat. Pada infeksi yang ringan, yaitu gejala subklinis dengan tanda-tanda yang tidak khas seperti influensa. Masa inkubasi infeksi ini berlangsung 210 hari. $^{2}$ Infeksi VHS ditandai dengan adanya lesi khas vesikoulseratif pada oral dan atau perioral, kebanyakan mengenai anak-anak umur 1-5 tahun. Gejala prodromal berupa demam, sakit kepala, malaise, dan muntah disertai rasa tidak nyaman di mulut. Pada satu sampai dua hari setelah gejala prodromal,timbul lesi-lesi lokal berupa vesikel kecil berkelompok di mukosa mulut, berdinding tipis yang dikelilingi oleh peradangan. Vesikel cepat pecah, meninggalkan ulkus dangkal dan bulat yang nyeri di sekitar rongga mulut. Lesi dapat mengenai seluruh bagian di mukosa mulut. Selama berlangsungnya penyakit, vesikel dapat bersatu menjadi lesi yang lebih besar dengan tepi tidak teratur. Gambaran khas adalah gingivitis marginalis akut, generalisata, edema, dan eritema gingiva, yang kadang-kadang disertai beberapa ulkus pada gingiva. Pada pemeriksaan intra, faring posterior akan tampak kemerahan dengan pembesaran kelenjar getah bening submandibula dan servikal. $^{4}$

Pemeriksaan penunjang, antara lain meliputi pemeriksaan biopsi, titer antibodi, dan kultur virus maupun dengan mikroskop elektron direk. Diagnosis ditegakkan melalui anamnesis yang adekuat dan gambaran klinis serta hasil pemeriksaan penunjang di laboratorium. ${ }^{5}$

Terapi bagi penderita VHS meliputi kausatif disertai analgesik dan antipiretik, pemberian terapi suportif seperti makanan yang cair tinggi kalori dan protein, multivitamin, serta obat kumur dengan kandungan anastetikum. ${ }^{6}$

\section{KASUS}

Seorang laki-laki berusia 10 tahun datang ke Rumah Sakit Gigi dan Mulut Pendidikan Halimah Dg. Sikati dengan keluhan rasa sakit pada sudut bibir sebelah kiri dan mukosa bibir bawah yang dialami sejak tiga hari yang lalu. Dua hari sebelumnya, pasien mengalami demam, meriang, serta merasa lemas. Tujuh hari yanglalu ditemukan luka yang sama pada sudut bibir sebelah kanan. Kondisi ini sudah seringkali dialami pasien.

Pada saat pemeriksaan ekstraoral, kelenjar submandibularis kanan dan kiri teraba lunak dan terasa nyeri. Terdapat krusta pada bibir bawah regio kiri masing-masing berdiameter $5 \mathrm{~mm}$ dan $4 \mathrm{~mm}$ dengan tepi yang eritematous (gambar 1 dan 2). Pada pemeriksaan intraoral tampak dua ulkus pada mukosa labial rahang bawah berbentuk bulat, di bagian tengah tampak pseudomembran putih kekuningan dengan tepi berbatas jelas dan tampak eritema. Ulkus masing-masing berukuran diameter $2 \mathrm{~mm}$ dan $3 \mathrm{~mm}$. Terlihat hiperemi pada seluruh daerah marginal gingiva, khususnya di regio gigi 12 (gambar 3 ).

\section{PENATALAKSANAAN}

Pada kunjungan pertama, berdasarkan hasil anamnesis diketahui penderita mengalami demam sejak 3 hari sebelum kunjungan ke rumah sakitsetelah satu minggu sebelumnya juga pernah mengalami demam dan lesi yang sama di bibir kiri bawah yang akhirnya sembuh sendiri. Dari pemeriksaan klinis diketahui pasien menderita sariawan pada rongga mulut sertakemerahan pada seluruh gingival margin, maka didiagnosis gingivostomatitis dengan diagnosis banding herpangina. Pasien mendapat terapi acylovir tablet $20 \mathrm{mg} 5$ kali sehari, vitamin B komplek, obat kumur Listerine 3 kali sehari, serta pemberian antipiretik paracetamol.
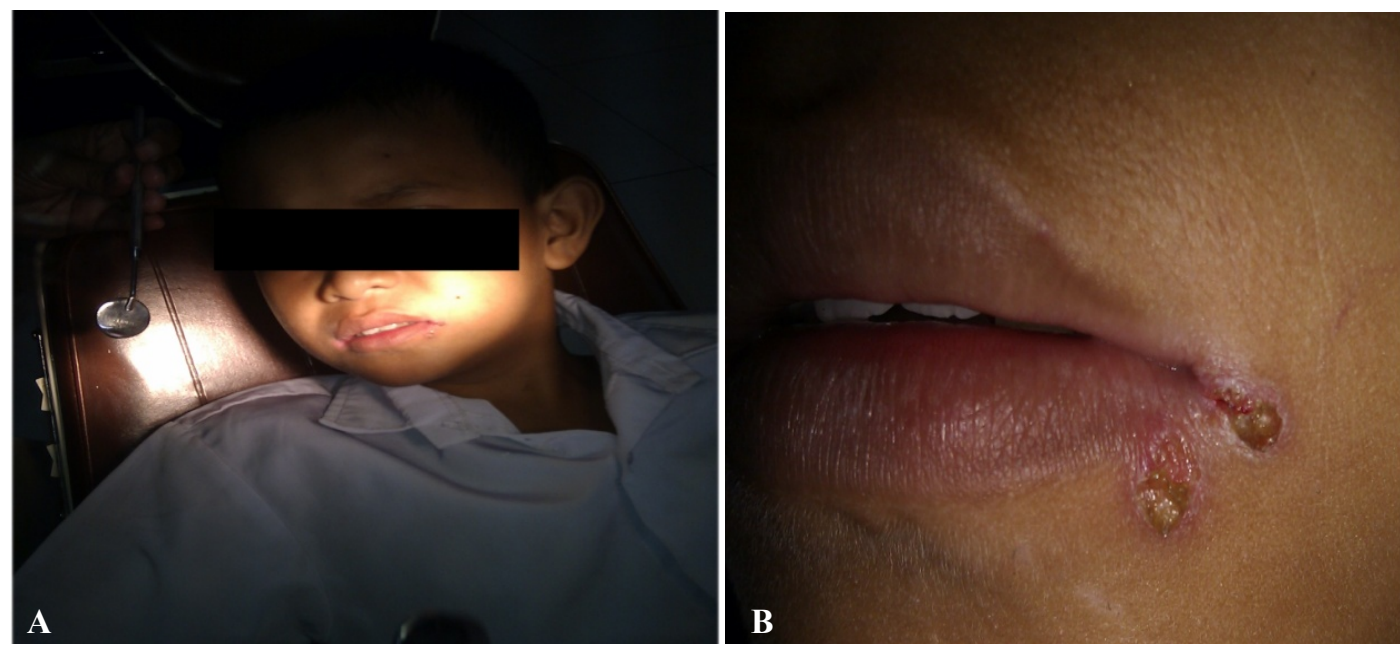

Gambar 1A \& B Krusta pada bibir bawah regio kiri masing-masing berdiameter $5 \mathrm{~mm}$ dan $4 \mathrm{~mm}$ yang bertepi eritematous 

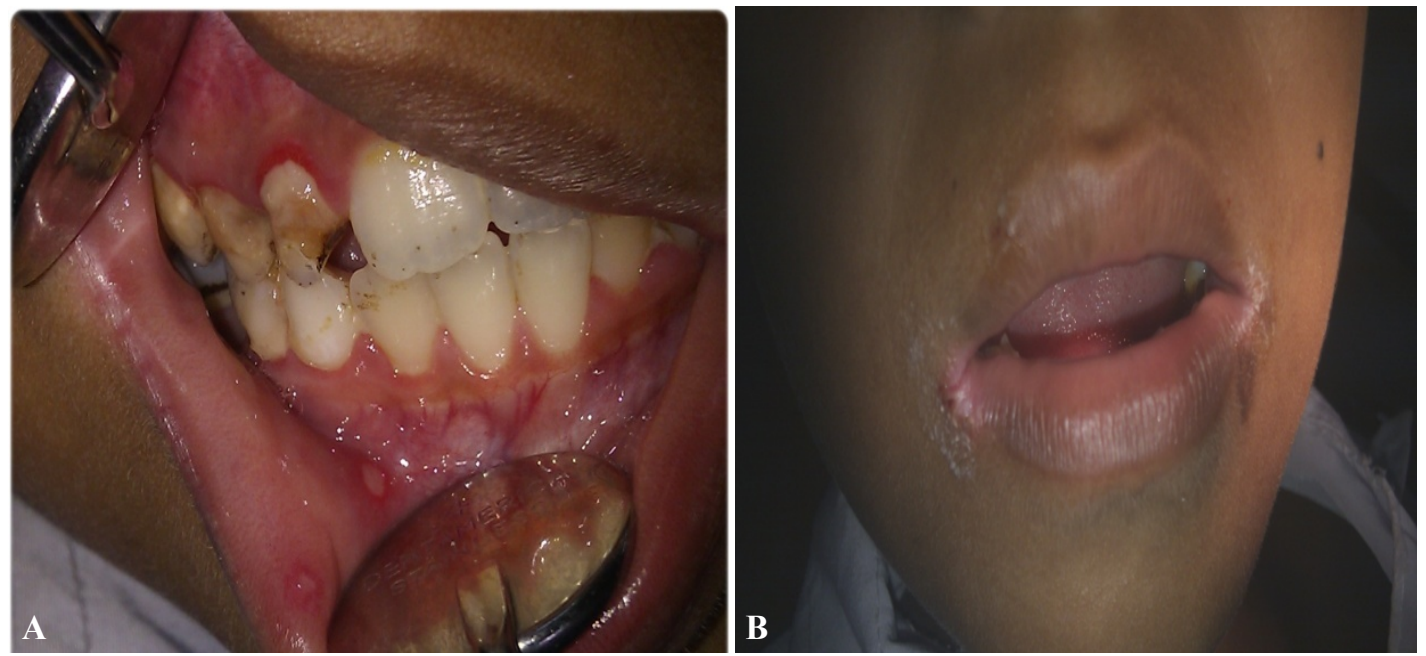

Gambar 2A Hiperemi pada seluruh daerah marginal gingiva, khususnya di regio gigi 12, B tampak ada krusta pada bibir regio kanan atas serta bibir regio kanan bawah dengan diameter masing-masing $3 \mathrm{~mm}$ dan $4 \mathrm{~mm}$

Anjuran yang diberikan adalah diet tinggi kalori dan protein, istirahat yang cukup, serta isolasi agar tidak terjadi penularan virus. Pasien diinstruksikan kontrol 3 hari berikut untuk melihat perkembangan penyembuhan penyakit serta mewaspadai terjadinya infesi sekunder.

Setelah kontrol hari ketiga terlihat penyembuhan ulser di mukosa labial inferior serta penyembuhan pada krusta di bibir kiri bawah yang ditandai dengan tidak adanya rasa nyeri pada mukosa labial serta labium inferior sinistra. Tujuh hari kemudian, terlihat adanya tanda penyembuhan pada bibir bawah kiri namun tampak adanya krusta pada bibir regio kanan atas serta bibir regio kanan bawah dengan diameter masing-masing $3 \mathrm{~mm}$ dan $4 \mathrm{~mm}$ (Gambar 4). Karena terlihat adanya lesi yang sama pada bibir atas dan bawah kanan, dosis oral ditambah seperti dosis orang dewasa menjadi 200 mg sebanyak 4 kali sehari lalu pasien diminta untuk kontrol 1 minggu kemudian untuk memantau penyembuhan penyakit.

Dari hasil anamnesis tidak tidak lagi ditemukan adanya rasa sakit pada bibirkanan. Hasil pemeriksaan ekstra oral normal, sedangkan pemeriksaan intra oral ulkus pada mukosa labial serta kemerahan pada marginal gingiva sudah tidak tampak lagi sehingga pasien dinyatakan sembuh.

\section{PEMBAHASAN}

Herpes simplek labialis (coldsore/fever blisters) adalah bentuk herpes orofasial rekuren yang paling sering terjadi, tampak berupa vesikel-vesikel pada batas luar vermilion dan kulit sekitarnya. Gejala dimulai dengan rasa perih diikuti oleh timbulnya vesikel berkelompok dalam waktu 24 jam, pecah, terjadi erosi superfisial, kemudian ditutupi krusta. Nyeri dan rasa tidak nyaman terjadi pada beberapa hari pertama, kemudian lesi sembuh dalam waktu kurang dari 2 minggu tanpa jaringan parut. Pelepasan virus terus berlangsung 3-5 hari setelah lesi sembuh. Herpes labialis rekuren terjadi pada $50-75 \%$ individu yang terkena infeksi VHS di mulut, dan terjadi tiga kali lebih sering pada pasien yang mengalami demam dibandingkan pasien tanpa demam. ${ }^{4}$

Herpes intra oral rekuren merupakan bentuk rekuren berupa lesi pada intra oral khususnya daerah mukosa yang berkeratin. Predileksi pada palatum durum regio premolar dan molar, dapat juga timbul pada bagian fasial dan bukal gingiva; vesikel mudah pecah, terletak unilateral, dan tidak melewati garis tengah. ${ }^{4,7}$

Umumnya VHS pada anak tidak bergejala atau bergejala sangat ringan, sehingga baik anak maupun orang tuanya tidak menyadarinya. Sebuah penelitian menyatakan bahwa hanya $10-12 \%$ anak yang pernah terinfeksi. Infeksi primer lebih berat sebab adanya limfadenopati, meriang, dan demam. Oleh karena itu penting untuk membedakan infeksi primer dan infeksi sekunder. ${ }^{8}$

Pada marginal gingiva didapati ada kemerahan serta mudah berdarah karena terjadi peningkatan kerentanan dan permeabilitas kapiler. Secara teori, diagnosis akhir dapat ditegakkan berdasarkan hasil anamnesis dan pemeriksaan klinis pada pasien yang sudah sangat jelas, meskipun tanpa pemeriksaan biopsi, kultur virus, serologi maupun mikroskop elektron. Pada kasus ini tidak dilakukan pemeriksaan apapun sebab pertimbangan waktu pemeriksaan yang lama sementara penyakit ini adalah penyakit selflimiting. Acyclovir diberikan karena merupakan terapi efektif terhadap herpes simplek. Acyclovir adalah analog nukleosida purin asiklik yang efektif terhadap VHS, virus Varicella zoster, Epstein barr 
dan Cytomegalovirus. Di dalam sel, acyclovir akan mengalami proses fosforilasi menjadi bentuk aktif, yaitu acyclovir trifosfat yang menghambat DNA polymerase VHS dan replikasi DNA virus dengan cara memutuskan rantai DNA, sehingga mencegah sintesis DNA virus tanpa mempengaruhi proses sel yang normal. Indikasi penggunaan acyclovir adalah mengobati herpes simplek genital, herpes labialis, herpes zoster, VHS ensefalitis, VHS neonatal, VHS mukokutan pada pasien yang memiliki respon imun yang diperlemah atau immunocompromised, dan varicella-zoster. Sedangkan kontraindikasi acyclovir adalah hipersensitivitas pada acyclovir, valacyclovir, atau komponen lain dari formula. Acyclovir juga memiliki efek samping pada sistem saraf pusat; dilaporkan terjadi malaise sekitar $12 \%$, sakit kepala $2 \%$, gangguan sistem pencernaan berupa mual $2-5 \%$, muntah 3\%, diare 2-3\%. Dosis obat antivirus untuk terapi herpes simplek labialis pada orang dewasa berupa acyclovir oral $400 \mathrm{mg} 2$ kali sehari, acyclovir topikal 5\% krim 5 kali sehari. Sedangkan dosis untuk anak-anak acyclovir oral $20 \mathrm{mg} /$ hari dan acyclovir topikal 5\% krim 5 kali sehari. ${ }^{1}$

Disimpulkan bahwa terapi bagi penderita infeksi VHS meliputi terapi kausatif disertai analgesik dan antipiretik, diikuti pemberian terapi suportif seperti makanan cair tinggi kalori dan protein, multivitamin, serta obat kumur anastetik.

\section{DAFTAR PUSTAKA}

1. Wayne RG, Michael GA. Reccurent herpes simplex labialis: selected therapeutic options. J Can Dent Assoc 2003; 69 (8): 498-503

2. Regezi, Sciuba, Jordan. Oral pathology : clinical pathology correlations. $4^{\text {th }}$ Ed. Philadelphia: Saunders; 2003. p.1-5

3. Thomas J, Liesegang. Herpes simplex virus epidemiology and ocular importance. Cornea 2001; 20(1): 1-13

4. Adolf H. Infeksi herpes pada pasien imunokompeten. PKB "New Perspective of Sexually Transmitted Infection Problems." Surabaya 7-8 Agustus 2010. p.1-10

5. Ajar AH, Chauvin PJ. Acute Herpetic gingivostomatitis in adult. J Can Dent Assoc 2002; 68: 247

6. Laskaris G. Treatment of oral disease: a concise textbook. Thieme; 2005. p.84-5

7. Fatahzadeh M, Schwartz RA. Human herpes simplex virus infections: epidemiology, pathogenesis, symptomatology, diagnosis, and management. J Am Acad Dermatol 2007; 57: 737-63

8. Harner G. Ano-genital herpes in children incidence of herpes simplex infection. J Pediatr Health Care 2006;20: 106-4 